Ethiopian Journal of Environmental Studies \& Management 8(Suppl. 2): 926 - 938, 2015.

ISSN:1998-0507

doi: http://dx.doi.org/10.4314/ejesm.v8i2.7S

Submitted: July 18, 2015

Accepted: November 09, 2015

\title{
IDENTIFICATION OF SOIL EROSION HOTSPOTS IN JIMMA ZONE (ETHIOPIA) USING GIS BASED APPROACH
}

\author{
*BESHIR KEDDI LENCHA ${ }^{1}$ AND AWDENEGEST MOGES ${ }^{2}$ \\ ${ }^{1}$ School of Water Resources Engineering, Hawassa University, Ethiopia P.O.Box 05 Hawassa \\ ${ }^{2}$ School of Bio-Systems and Environmental Engineering, Hawassa University, Ethiopia
}

\begin{abstract}
The objective of this research was to examine spatial patterns of soil erosion, identify erosion hotspots and investigate the impact of land use changes on spatial patterns of soil erosion in the Jimma zone, Western Ethiopia. The area is one of the regions that produce coffee which is an export commodity and known for its good forest cover and undulating topography. Additionally, the rivers in the area are currently being developed for hydropower generation and more hydropower projects have been proposed by government downstream. Universal Soil Loss Equation (USLE) coupled with GIS was used to identify areas that are susceptible for soil erosion and hotspots for erosion. The impact of land cover change was assessed through the analysis of readily available NDVI imagery. About 14.3 and 18.1 percent of the area fall in the very high erosion risk class (>50 metric tons ha-1yr-1) for the years periods (2001 and 2013) considered for this study respectively. Moreover, the total soil loss in the study area $(1,824,878 \mathrm{ha})$ for the year 2001 and 2013 was found to be $90.2 \times 10^{6}$ and $115.9 \times 10^{6}$ metric tons respectively. The result of the analysis indicates that within 10 years period (2001-2013), there was an increment in erosion potentials (susceptibility) and parts especially with undulating topography where crop production practiced is much susceptible for erosion. More interestingly, four out of five districts with very high erosion susceptibility levels are those that drain to a reservoir of one of the important hydro power plant that have cascading dams downstream and calls for immediate intervention.
\end{abstract}

Key Words: Erosion, GIS, USLE, NDVI, Ethiopia, Hotspot.

\section{Introduction}

Erosion is an inclusive term for the detachment and transport of soil by the action of erosive agents: water and wind, and influenced by factors such as climate, soil, vegetation, and topography (Niu et al., 2003; Demirci and Karaburun 2012). Soil characteristics like soil particles size (texture), organic matter content and permeability determine the vulnerability of a soil to erosion (USAF 2009). Most concerns about erosion are related to

*Corresponding author: Beshir Keddi

Email: beshir1975@yahoo.com accelerated erosion, where the soil loss rate has been significantly increased by human activities such as changes in land cover and management (Gobin et al., 2002).

Erosion is one of the biggest global environmental problems resulting in both on-site and offsite effects which have economic implications and an essential actor in assessing ecosystem health and function (Niu et al., 2003). It is one of the major and most widespread forms of land degradation that creates difficulty to 
sustainably use agricultural lands (Gobin $e t$ al., 2002; Omar et al., 2013).

Soil erosion especially water erosion on cropland is one of the most severe problems affecting the agricultural sector in Ethiopia (Shiferaw and Holden, 1999; Sonneveld 2002). An alarming message indicated that (FAO 1998a; Sonneveld 2002), Ethiopia could lose nearly all its top soil within 100-150 years which will have significant negative impacts on the ecological balance and the livelihood of the society. Study conducted by Devi et al. (2008) in the Gilgel Gibe catchment at one of the tributary of the Gilgel Gibe I dam, taking the contribution of sheet erosion alone found the annual sediment load to be about $4.50 \times 10^{7}$ tons. Additional study (Kissi et al., 2011) indicated that suspended sediment yield of the tributaries in Gilgel-Gibe catchment to be in the range of 0.43-132.08 tons per hectare per year and the soil loss due to landslide alone in the past 20 years to be about 11 tons/ha/yr. Other soil loss study (Kebede and Mikru 2006; Kebede and Yaekob 2009) estimated an annual soil loss rate of $82.3 \mathrm{t} /$ ha.

Estimates of erosion are essential. Variations in soil type, topography, and land cover lead to different sensitivity to erosion, thereby making soil erosion control a difficult task.Thus, identifying areas with high erosion risk will have a great benefit in order to plan site-specific management interventions and allocate resources efficiently (Tamene and Vlek, 2008; Tesfahunegn, 2011) and for effective land use management (Saavedra, 2005).

Conventional methods like mapping susceptible areas based on field surveys
(Kumar and Kushwaha, (2013) and (R)USLE (Andrello et al., 2004), have been found difficult due to cost and time implications. A more systematic approach like GIS based erosion modeling (USLE based on GIS) which is flexible, timesaving and cost-effective tool can be used instead for larger scale studies.

In spite of rapid loss of storage volume and power generation capacity of Gilgel Gibe I reservoir due to erosion and sedimentation (Devi et al., 2008; Kissi et al., 2011), we lack basic knowledge on the extent of soil erosion rate, erosion hotspots and how land use change is aggravating the situation. Therefore there is a need to examine spatial patterns of soil erosion and identify erosion hotspots in the Jimma zone. The study also attempts to investigate the impact of land use changes on spatial patterns of soil erosion.

\section{Study Area}

Jimma Zone is one of the 18 zones within Oromia regional states and divided into 13 districts with population of over 2.2 million (Tolossa and Tigre, 2007). It has an agro-ecological setting of highlands (15\%), midlands (67\%) and lowlands (18\%), (Dechassa, 2000). It lies between 7 ${ }^{\circ} 15^{\prime}-8^{\circ} 45^{\prime} \mathrm{N}$ and $35^{\circ} 30^{\prime}-37^{\circ} 30^{\prime} \mathrm{E}$, and the elevation ranges from $880 \mathrm{~m}$ to $3360 \mathrm{~m}$ above sea level (Tolossa and Tigre, 2007) and covers an area of $18,483.4 \mathrm{~km}^{2}$. The climate is humid tropical with bimodal rain fall, ranging from 1200 to $2800 \mathrm{~mm}$ (JZMSR, 2004). In normal years, the rainy season extends from February to early October. The soil type of the study area is dominated and characterized as black to red soils (Kechero, 2008). 


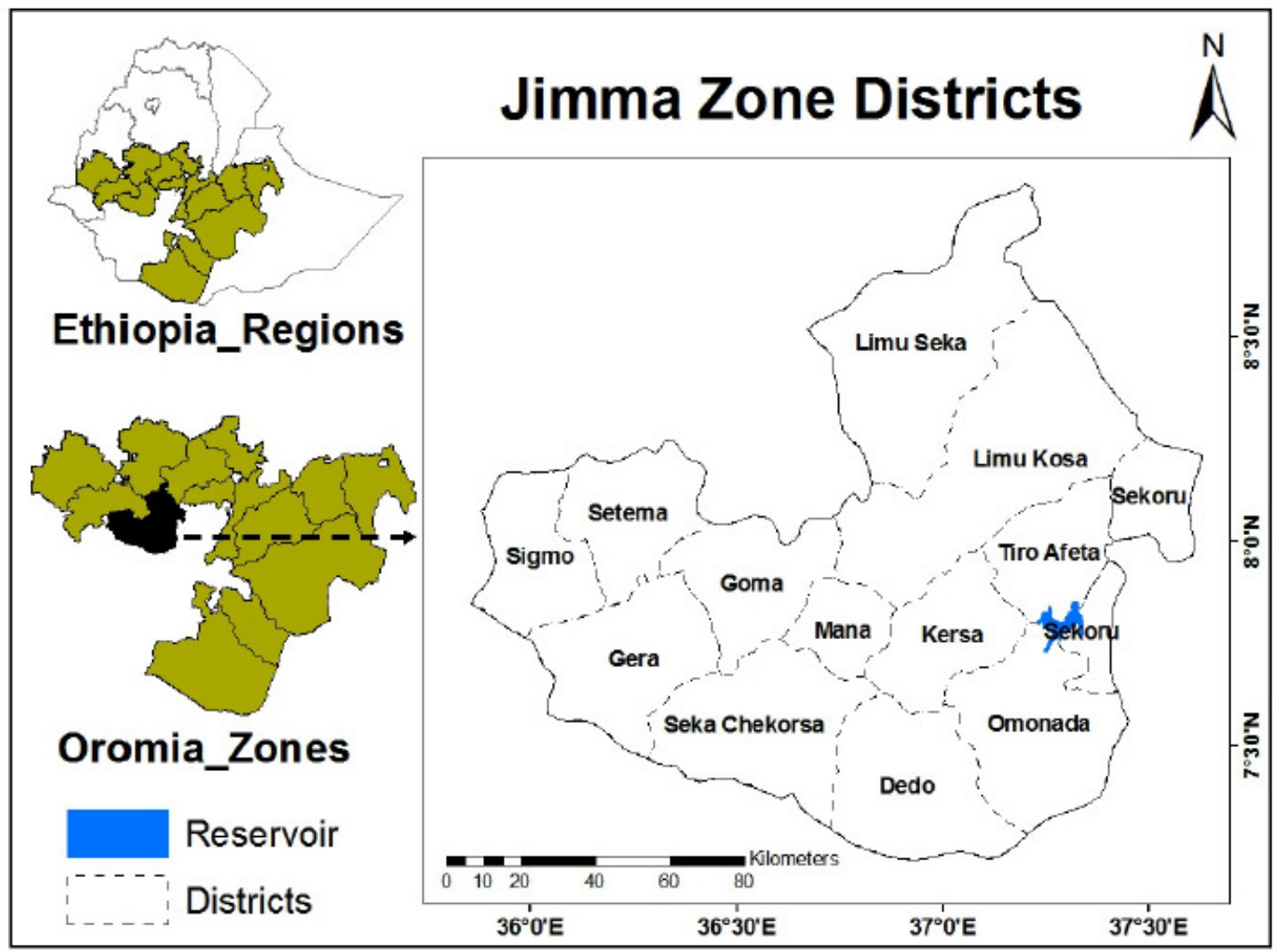

Figure 1: Location of the study area

\section{Methodology}

The study area was extracted from the shape file that indicates administrative zone and re-projected to UTM Adindan $37 \mathrm{~N}$. Then it was used to clip all digital data and all data sets then were defined and re-projected to the same projection.

R-Factor: The modified version of the Fournier index (MFI) (Ozsoy et al., 2012) was used to calculate the rainfall erosivity. The average monthly and mean annual rainfall (point data) data of 23 meteorological stations was used to determine the MFI and R-factor using equation Eq. (1) and Eq. (2) respectively.

$\mathrm{MFI}=\sum_{\mathrm{i}=1}^{12} \mathrm{P}_{\mathrm{i}}^{2} / \mathrm{P}$

Where $\mathrm{P}_{\mathrm{i}}$ is the precipitation total in month $\mathrm{i}$, and $\mathrm{p}$ is the mean annual precipitation.
The R-factor was calculated using the following equation:

$R=(4.17 * M F I)-152$

Where $\mathrm{R}=$ Rainfall erosivity factor

The R-factor was interpolated using kriging method within arcGIS to obtain spatial continuous data of R-value.

K-Factor: A soil map from FAO et al., (1998b) and FAO et al., (2009) were used and, soil erodibility factor was determined using relationships as suggested by Neitsch et al. (2002). K is taken as the product of four dimensionless empirical factors, which in turn are functions of sand, silt, clay, and organic carbon contents of the soil.

LS-Factor: A depression less (hydrologically corrected) Shuttle Radar 
Topography Mission (SRTM) digital elevation model (Jarvis et al., 2008) was used for the analysis of terrain attributes. Flow direction and flow accumulation were determined within ArcGIS following the standard procedures. A slope map was generated from the DEM and slope length and the steepness factor (LS-factor) determined as given by Moore and Wilson (1992).

C-factor: 2001 and 2013 NDVI images were used to determine the $\mathrm{C}$-factors using the relationship given by Van der Knijff $e t$ al. (1999)

Conservation Practice (P-factor): This was determined following the modified approach (Table 1). The approach was also used by Shiferaw (2011) in Borena and Bewket and Teferi (2009) in Ethiopia. The land cover map of the area used for this analysis was extracted from GLCF-2009.
Table 1: Conservation practice (P factors) based on slope and Land use (Shiferaw, 2011).

\begin{tabular}{lll}
\hline Land Use Type & Slope (\%) & P factor \\
\hline Agricultural land & $0-5$ & 0.11 \\
& $5-10$ & 0.12 \\
& $10-20$ & 0.14 \\
& $20-30$ & 0.22 \\
& $30-50$ & 0.31 \\
& $>50$ & 0.43 \\
Other land & all & 1.00 \\
\hline
\end{tabular}

\section{The USLE Model}

The annual soil erosion rate was estimated using the USLE model (Eq.3). The conceptual framework employed in ArcGIS environment is shown in Figure 2. Areas with the various erosion levels (hotspot) were determined by classifying them in to four susceptibility levels: Low (0 - $10 \mathrm{t} / \mathrm{ha} / \mathrm{yr})$, Moderate (10 - $25 \mathrm{t} / \mathrm{ha} / \mathrm{yr})$, High $(25-50 \mathrm{t} / \mathrm{ha} / \mathrm{yr})$ and very high (> $50 \mathrm{t} / \mathrm{ha} / \mathrm{yr})$.

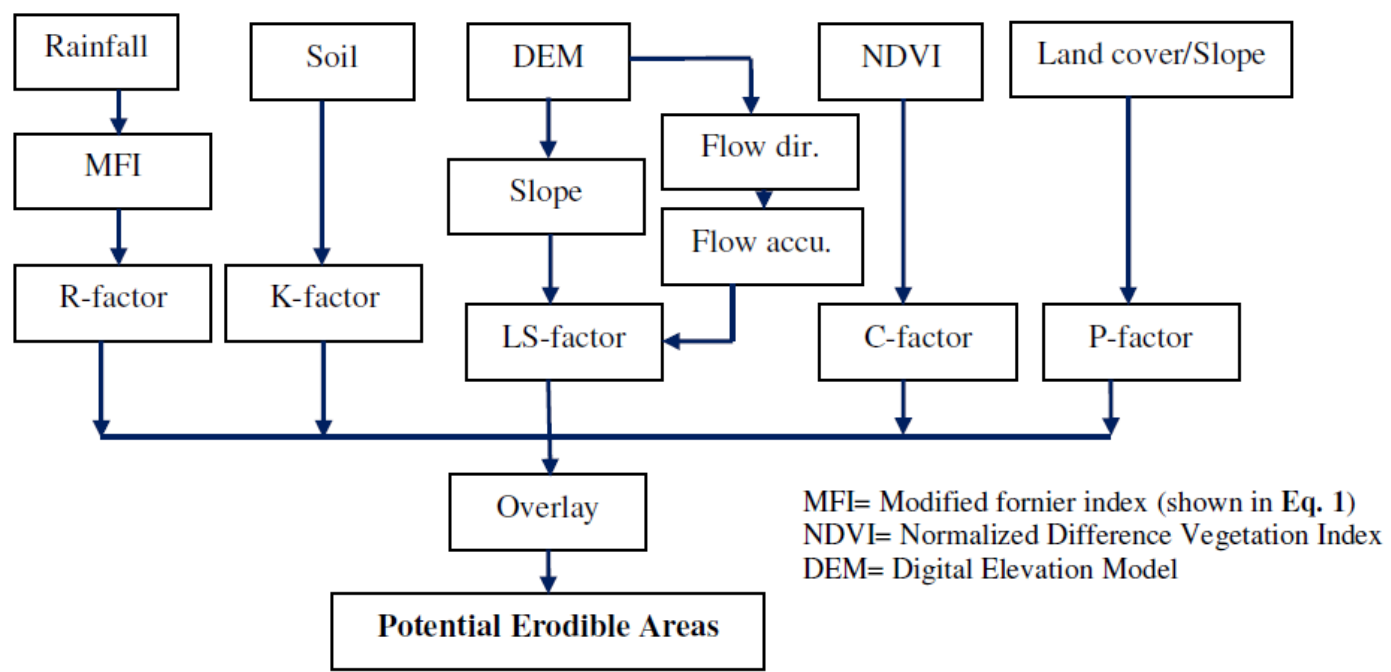

Figure 2: Conceptual framework of the method employed

\section{$A=$ R K LS C P}

Where $\mathrm{A}=$ Average Annual Soil Loss in tons/ha/yr

$\mathrm{R}=$ Rainfall erosive index factor $(\mathrm{MJ} \mathrm{mm} / \mathrm{ha} \mathrm{hr} \mathrm{yr}$ )

$\mathrm{K}=$ Soil Erodibility factor (ton ha $\mathrm{hr} / \mathrm{ha} \mathrm{MJ} \mathrm{mm}$ )

$\mathrm{S}=$ Slope steepness factor (dimensionless)

$\mathrm{L}=$ Slope length factor (dimensionless)

$\mathrm{C}=$ Crop-Management factor (dimensionless)

$\mathrm{P}=$ Conservation Practice Factor (dimensionless) 


\section{Results and Discussion USLE Factor}

The mean values of rainfall erosivity $(\mathrm{R})$, soil erodibility $(\mathrm{K})$, topographic (LS) cover $(\mathrm{C})$ and management $(\mathrm{P})$ factors are shown in Figure 3. The rainfall erosivity factor, R, ranges from 547.6 -1118.3 MJ $\mathrm{mm} / \mathrm{ha} \mathrm{hr}$ yr. It is clear from the map (Figure 3) that the Northern and Western part have large value, which corresponds to areas with high rainfall. About $11 \%$ of the area has $\mathrm{R}$ factor of over $1000 \mathrm{MJ}$ $\mathrm{mm} / \mathrm{ha} \mathrm{hr} \mathrm{yr} .35 \%$ of the area has $\mathrm{R}$ value of less than $700 \mathrm{MJ} \mathrm{mm} / \mathrm{ha} \mathrm{hr} \mathrm{yr} .40$ and $14 \%$ of the area has $\mathrm{R}$ factor in the range of 700-900 and 900-1000 MJ mm/ha hr yr respectively.

The soil erodibility factor $(\mathrm{K})$ was found to be in the range of 0.238-0.292 ton ha $\mathrm{hr} / \mathrm{ha} \mathrm{MJ} \mathrm{mm}$. Soil found in the central part has the highest $\mathrm{K}$-factor.

According to FAO et al. (1998b), soils are texturally fall in clay and clay loam. The result of the analysis of K-factor values are in agreement with values proposed by Stone and Hilborn (2000) for these textural classes and given by Hurni (1985) for Ethiopian soils based on soil color. According to Stone and Hilborn (2000), K-factor values are in the range of $0.22-0.30$ for clay and clay loam soils. According to Hurni (1985) soils which are black or red /grey and similar to soils of the study area have K-factor that falls in the range of $0.15-0.25$. The results of previous studies are approximately closer to the results of the empirical equation used for this study.

The LS factor is in the range of 0 412.7. The elevation is in the range of 842 to $3345 \mathrm{~m}$. The southern, central and northern parts have relatively higher elevation with undulating topography. As can be seen from Figure 3, they have relatively higher LS factor as compared to other parts. Further analysis shows that only an area of about $4 \%$ has LS factor value of over 50 .

The C-factor, determined empirically from NDVI values, were found to be in the range of $0.005-0.6065$ for the year 2001 and $0-0.98$ for the year 2013. The eastern and northern parts, known to be largely agrarian, have relatively larger C-factor values while the western with high forest cover have relatively smaller C-factor values. Comparison of the $\mathrm{C}$-factor values in the year 2001 and 2013 shows significant variation (Figure 3) which could be attributed to further expansion of agriculture (cultivation) to marginal areas and perhaps more degradation that lead to change in land cover. 


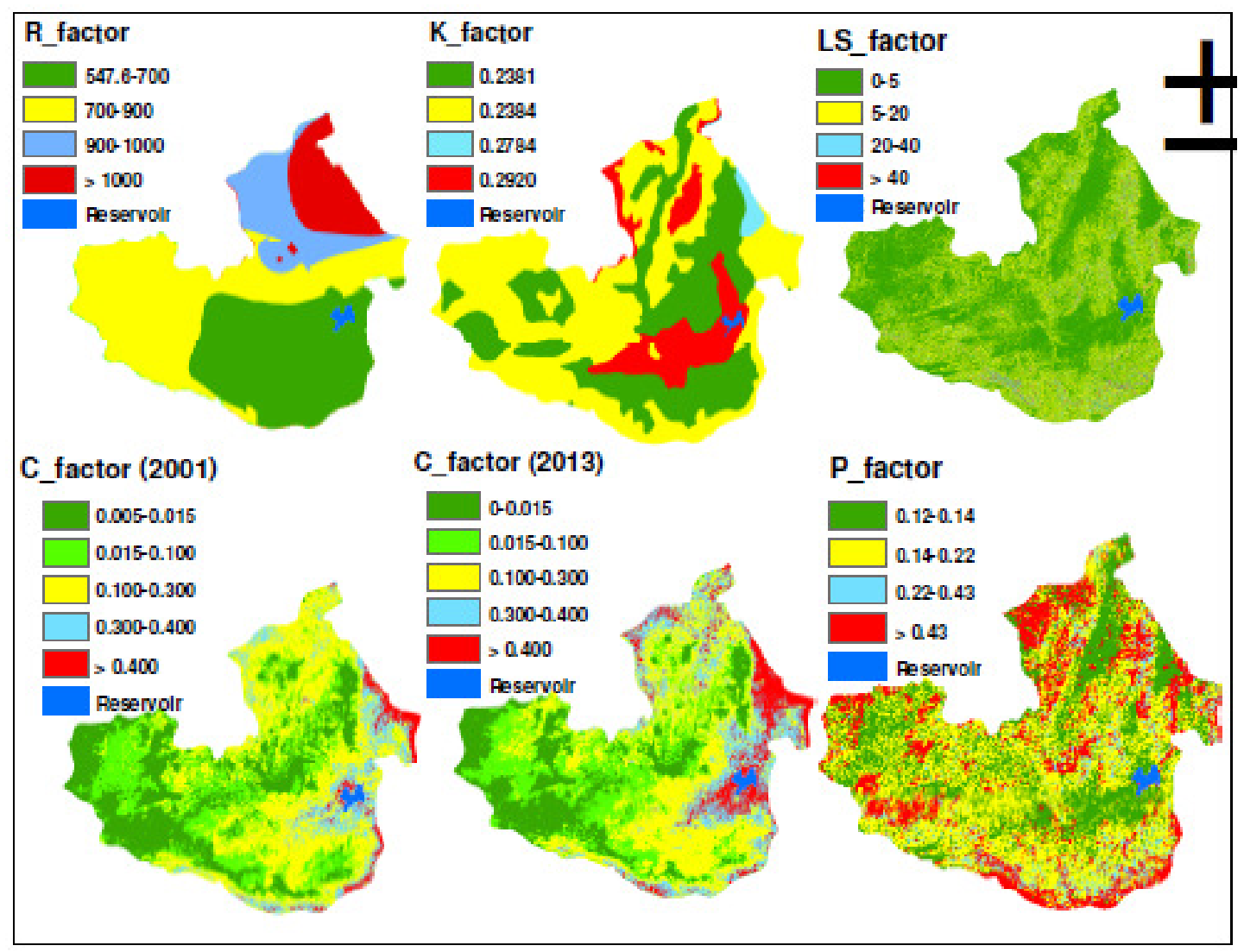

Figure 3: USLE factors

The $\mathrm{P}$ factor was in the range of 0.11 to 1.00. The central part has relatively lower $\mathrm{P}$ values as compared to the north east, southern, eastern and western part. Generally the distribution of the $\mathrm{P}$ value does not show any trend which indicates no variation in land cover types and topography (Slope).

\section{Erosion Susceptibility classes and distribution}

The potential annual soil loss, calculated by overlaying the USLE factors with a help of raster calculator function within ArcGIS 9.3 using eq. 1 is shown in Figure 4. The estimated annual soil loss ranged from 0 to over 50 tons per hectare per year.

The USLE result was classified into four erosion susceptibility classes as shown in Table 2. The result shows that about $14.3 \%$ and $18.1 \%$ of the area fall in the very high erosion risk class ( $>50$ t/ha/yr) in 2001 and 2013 respectively which indicates the severity of erosion in the area. $67.3 \%$ of the study area was found to have soil loss below $10 \mathrm{t} / \mathrm{ha} / \mathrm{yr}$ in 2001 which decreased to $62.4 \%$ in 2013. $11.2 \%$ of the area was found to have moderate erosion losses (10-25 t/ha/yr) which did not show any variation in both periods considered for the analysis. An area of about $7.2 \%(2001)$ and $8.3 \%$ (2013) have high erosion rate (25-50 t/ha/yr).

The spatial locations of the hotspot areas (above $50 \mathrm{t} / \mathrm{ha} / \mathrm{yr}$ ) (Figure 4) revealed that the potential soil loss is higher in the southern, eastern, and north western parts which correspond to high Cfactor, LS-factor and P-factor values (Figure 3). The western part has relatively low C-factor values (Figure 3 ) shows the least vulnerability to soil erosion. 


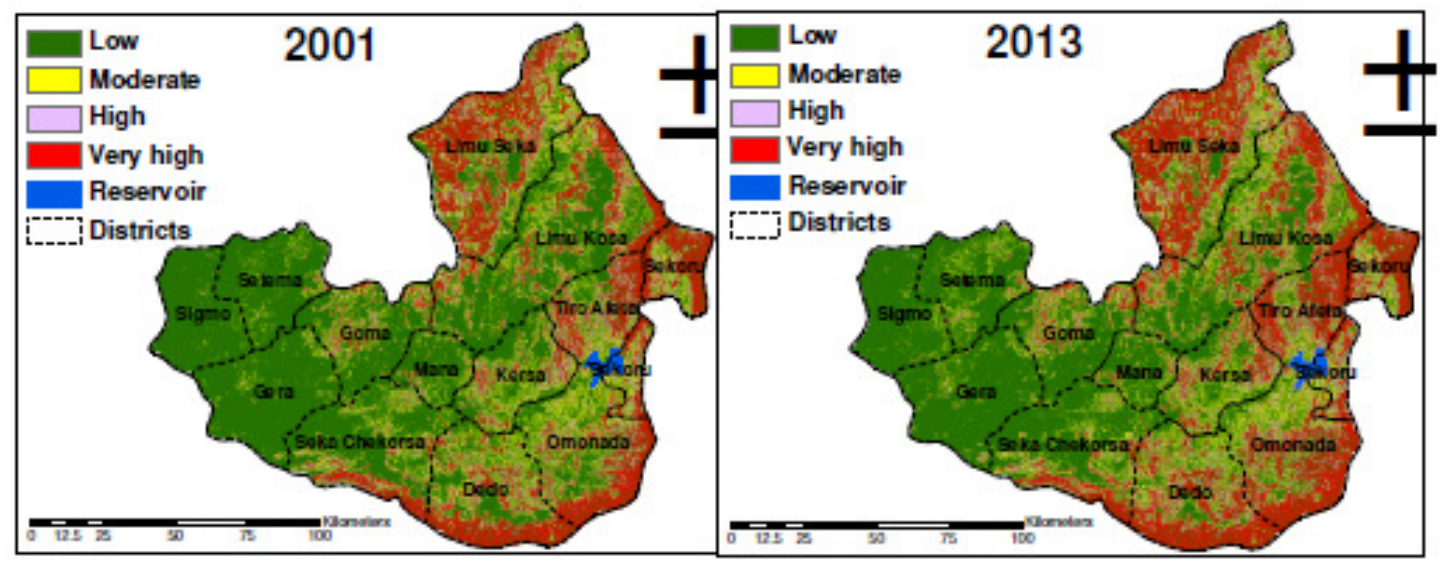

Figure 4: Erosion Susceptibility Levels for the year 2001 and 2013

The mean annual potential soil loss of the districts for the year 2001 is $48.1 \mathrm{t} / \mathrm{ha}$ and generally falls in the range of 0.9$200.2 \mathrm{t} / \mathrm{ha}$. For the year 2013, the mean is $60.9 \mathrm{t} / \mathrm{ha}$ and ranges from 1.6 to $232.4 \mathrm{t} / \mathrm{ha}$. The total soil loss in the area $(1,824,878$ ha) for the year 2001 and 2013 is found to be $90.2 \times 10^{6}$ and $115.9 \times 10^{6}$ metric tons respectively. This result is in agreement with the findings of previous studies done in the nearby areas and other parts of the country with similar terrain and climatic factors by Kebede and Mikru (2006), Bewket and Teferi (2009) and Shiferaw (2011). Based on the research done in small catchment found in the study area, Kebede and Mikru (2006) found that about 82.3 ton ha ${ }^{-1}$ soil is eroded annually. Bewket and Teferi (2009) have found an average soil loss in the range of $7-243 \mathrm{t} / \mathrm{ha} / \mathrm{yr}$ for a catchment in the Blue Nile basin. Hawando (1995) showed that the annual soil loss of the highlands of Ethiopia ranges from 16-300 tons/year per hectare of pasture ranges and cultivated fields throughout Ethiopia. Bobe (2004) estimated soil loss for sites in the eastern part of Ethiopia with similar topography to be in the range of 2.60-116.94 t/ha/yr. Shiferaw (2011) found an erosion rate in the range of 80- $54 \mathrm{t} / \mathrm{ha} / \mathrm{yr}$ for similar areas in the northern Ethiopia. Even if the severity is a bit very large in areas with rugged topography (high LS factor) coupled with heavy rainfall (R-factor) and poor land cover (C-factor), the result of the analysis is in line with previous estimations and measurements shown above.

The analysis for the year 2001 (Table 3) indicates that five districts (Sekoru, Limu Seka, Dedo, Omo Nada and Tiro Afeta) have over $21 \%$ of their area that falls in the very high erosion class (Over 50 tons/ha/yr). Five districts (Sigmo, Gera, Setema, Mana and Goma) have an area of less than $6 \%$ in the very high susceptibility class and the rest three districts (Kersa, Seka Chokorsa and Limu Kosa) have about $7.6 \%, 8.5 \%$ and $12.2 \%$ of their area under very high susceptibility class. The result of the year 2013 indicates the percent area of the above five districts that are in the higher risk class showed an increment. The value increased from $26.0 \%$ in 2001(Tiro Afeta) to $35.4 \%$ in 2013 . The same holds true for all the districts (Table 3 ) except the districts located in the western part where the increment was very small. 
Table 2: Percent area of districts under different soil erosion severity classes

\begin{tabular}{llllll}
\hline \multirow{2}{*}{$\begin{array}{l}\text { Potential Soil Loss } \\
\text { (tons/ha/yr) }\end{array}$} & $\begin{array}{l}\text { Susceptibility } \\
\text { class }\end{array}$ & 2001 & \multicolumn{3}{l}{2013} \\
\cline { 3 - 6 } & Area $\left(\mathrm{Km}^{2}\right)$ & \% of total area* & Area $\left(\mathrm{Km}^{2}\right)$ & $\%$ of total area* \\
\hline $0-10$ & low & 12,281 & 67.3 & 11,398 & 62.4 \\
$10-25$ & Moderate & 2,051 & 11.2 & 2,035 & 11.2 \\
$25-50$ & High & 1,318 & 7.2 & 1,510 & 8.3 \\
$>50$ & Very high & 2,599 & 14.3 & 3,306 & 18.1 \\
\hline
\end{tabular}

*Excluding water body

Based on the spatial distribution of erosion susceptibility levels determined for the year 2013 (Table 3), five of the districts: Sekoru, Tiro Afeta, Limu Seka, Dedo and Omo Nada, have at least around $28 \%$ of their area that fall under very high erosion susceptibility class (> $50 \mathrm{t} / \mathrm{ha} / \mathrm{yr})$. As can be seen from table 3 , these districts have about $37 \%, 35 \%, 34 \%, 30 \%$ and $28.5 \%$ of their area respectively that fall in the higher erosion susceptibility class. Limu Kosa, Kersa and Seka Chokorsa have about $17.4 \%, 12.4 \%$ and $9.3 \%$ of their area under very high and extreme erosion susceptibility class. The rest of the districts have less than $7 \%$ of their area under very high and extreme susceptibility classes.

Overall, nine of the districts have about $15 \%$ and above of their area with erosion rate exceeding $22 \mathrm{t} / \mathrm{ha} / \mathrm{yr}$ the maximum allowable soil loss limit in Ethiopia (Figure 5). Moreover, the top five districts with very high erosion susceptibility levels (drain to the Gilgel Gibe dam) have area in the range of $40-52 \%$ with erosion greater than the maximum tolerable limit.

Table 3: Annual potential soil erosion rates and severity classes

\begin{tabular}{lllllllll}
\hline \multirow{2}{*}{ District } & Low & \multicolumn{4}{c}{ Moderate } & High & \multicolumn{3}{c}{ Very high } \\
\cline { 2 - 9 } & 2001 & 2013 & 2001 & 2013 & 2001 & 2013 & 2001 & 2013 \\
\hline Sigmo & 98.4 & 96.3 & 1.2 & 2.9 & 0.3 & 0.6 & 0.1 & 0.2 \\
Gera & 95.9 & 94.5 & 3.1 & 4.1 & 0.8 & 1.1 & 0.2 & 0.4 \\
Setema & 93.2 & 86.4 & 5.2 & 10.1 & 1.0 & 2.3 & 0.5 & 1.1 \\
Mana & 85.2 & 82.4 & 9.7 & 11.3 & 3.4 & 3.8 & 1.7 & 2.4 \\
Goma & 76.7 & 75.3 & 11.6 & 11.5 & 6.1 & 6.7 & 5.6 & 6.5 \\
Kersa & 64.5 & 58.3 & 17.9 & 17.6 & 10.0 & 11.6 & 7.6 & 12.4 \\
Seka Chekorsa & 75.1 & 74.3 & 10.9 & 10.8 & 5.4 & 5.6 & 8.5 & 9.3 \\
Limu Kosa & 68.8 & 60.1 & 11.9 & 13.1 & 7.0 & 9.3 & 12.2 & 17.4 \\
Omonada & 52.2 & 45.3 & 16.5 & 14.4 & 9.9 & 11.7 & 21.4 & 28.5 \\
Dedo & 53.2 & 45.9 & 13.8 & 13.2 & 9.4 & 11.0 & 23.6 & 29.9 \\
Tiro Afeta & 46.3 & 41.6 & 13.3 & 9.9 & 14.4 & 13.1 & 26.0 & 35.4 \\
Limu Seka & 48.7 & 43.7 & 12.6 & 10.9 & 10.5 & 11.5 & 28.2 & 33.9 \\
Sekoru & 39.9 & 38.3 & 13.8 & 11.6 & 12.4 & 13.2 & 33.8 & 37.0 \\
\hline
\end{tabular}




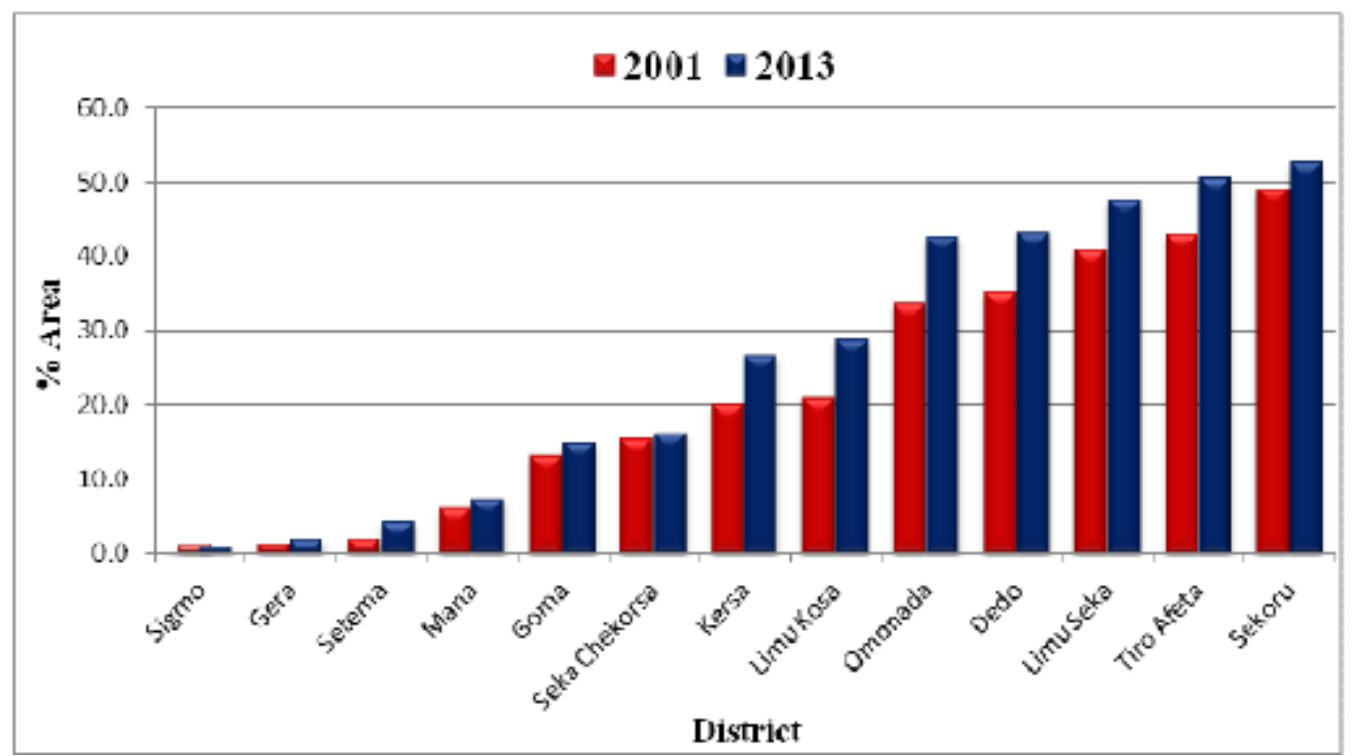

Figure 5: Areas with erosion over the allowable limits

Figure 6 shows districts in order of their susceptibility versus topographic (LS) factor and cover (C) factors. Even if it does not show a clear trend, districts with high potential erosion (high susceptibility) have high LS factor.

Districts with high erosion susceptibility have relatively high C-factors than LS factor. The trend (susceptibility) follow closely the C factor than LS which indicates cover to be more dominant factor in deciding the susceptibility level than LS.

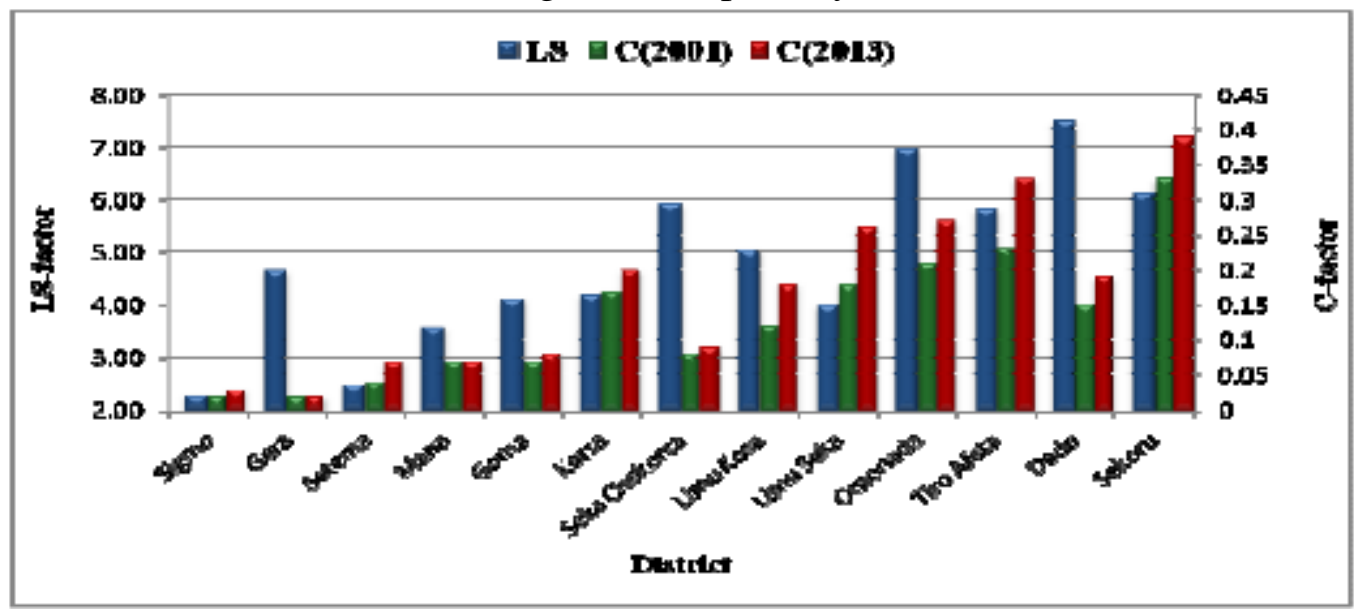

Figure 6: Topographic and cover factors of districts

However, R-factor does not show clear trend with erosion potential (Figure 7). Additionally, districts with less susceptibility to erosion (Goma, Mana, Setema, Gera, and Sigmo) have low k values (soil erodibility) which is approximately around 0.239 as compared to the five districts with high susceptibility (Sekoru, Tiro Afeta, Limu Seka, Omonada and Dedo) with K-factor values in the range of $0.25-0.26$.

From the comparison of R-factor (Figure 7) and C-factor (Figure 6), it can be seen that most of the districts with high rainfall have better land cover throughout the year which make them to be less susceptible for soil erosion as compared to other districts. 


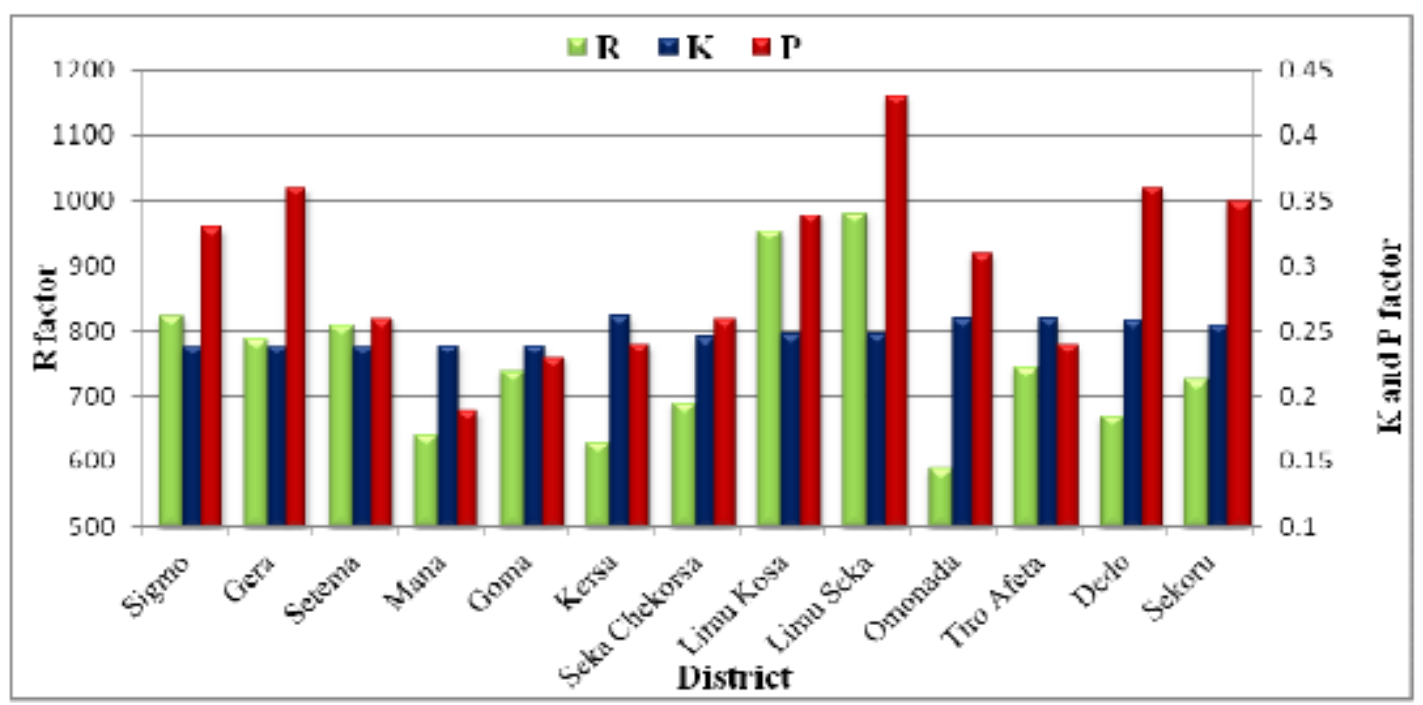

Figure 7: Rainfall erosivity and soil erodibility factors of districts

The management factor $(\mathrm{P})$ does not show any pattern (trend) with erosion susceptibility across the districts. Generally, except Tiro Afeta, all districts with very high erosion rate and known to have large agricultural area have large $\mathrm{P}$ value.

Four out of 5 districts (Dedo, Omo Nada, Sokoru and Tiro Afeta) with very high erosion susceptibility classes are those that have part of their area draining to the Gilgel Gibe I dam reservoir.

Both LS and C factors of these districts are relatively larger than other districts. The mean LS factor of these districts is in the range of 5.8 to 7.5 . The minimum mean $\mathrm{C}$-factor of the districts is 0.15 and the maximum is 0.39 . It is clear that in these districts, both slope and cover are the dominating factors except Dedo where slope is the major factor. So, mitigating soil erosion in these districts calls for management practices that focus more on soil conservation structures and improving cover factors for districts like Sokoru and Tiro Afeta.

Generally, managing or controlling soil erosion in these parts has an implication on the life and sustainable use of the dam and other cascading dams downstream. This calls for immediate intervention and mitigating measures to alleviate the current situation

\section{Conclusion}

The results of the USLE factor analysis overlaid within GIS to generate erosion risk map helps to compare and prioritize districts that need much attention which would help to allocate resources efficiently.

Among the USLE factors, C-factor was found to contribute much for soil erosion followed by LS factor. This gives an indication on how soil and water conservationist should focus on districts with less soil cover and rugged topography (high LS factor). The comparison of changes in susceptibility levels in 2001 and 2013 indicated that some of the areas which were in low susceptibility class in 2001 shifted to more susceptible class in 2013 (within 10 years). The use of NDVI has made the analysis and comparison of erosion susceptible areas much easier. So, GIS based analysis can be used for further analysis of such problems at different temporal levels like monthly based 
comparison. In addition to $\mathrm{C}$-factor analysis, different management scenarios (soil conservation measures) can be compared and used to make decision with regard to possible conservation measures and their immediate outcomes. The result showed that use of texture to estimate erodibility is adequate in the absence of the recommended large data sets.

Remote sensing based NDVI data and GIS based USLE analysis are helpful in areas with scarce land cover information with the required temporal resolution. The use of NDVI data of different periods also provides much contribution to look at how erosion susceptibility is increasing and even affecting areas that are considered to be with good forest cover and less human interference.

The potential soil loss of the study sites is variable and severe in five of the districts, out of which four districts are those that have full or part of their catchments draining to the Gilgel Gibe I dam. The results of this study indicated the need for immediate actions to alleviate the current situation especially in districts with the highest severity classes particularly to protect the dam from siltation.

\section{Acknowledgement}

The authors would like to thank Jimma University and Ethiopian Institute of Water Resources for supporting this research. The national meteorological agency of Ethiopia, Jimma meteorological station, Ministry of Water, Irrigation and Energy of Ethiopia provided us with relevant data, we are very grateful.

\section{References}

Andrello, A.C., Appoloni, C.R.C. and Guimaraes, M.F. (2004) Soil erosion determination in a watershed from Northern Paraná (Brazil) ising
137Cs. Braz. Arch. Biol.Technol. 47(4): 659-667.

Bewket and Teferi (2009). Assessment of soil erosion hazard and prioritization for treatment at the watershed level: Case study in the Chemoga watershed, Blue Nile basin, Ethiopia. Land Degradation and Development, 20(6):609-622.

Bobe, B.W. (2004). Evaluation of soil erosion in the Hararghe region of Ethiopia using soil loss model, rainfall simulation and field trials. $\mathrm{PhD}$ Thesis, University of Pretoria, South Africa. 218 pp.

Dechassa, L. (2000). Field Assessment Report: Jimma Zone of Oromia Region, UN-Emergencies Unit for Ethiopia.

Demirci, A. and Karaburun, A. (2012). Estimation of Soil Erosion Using RUSLE in A GIS Framework: A Case Study in the Buyukcekmece Lake Watershed, Northwest Turkey. Environmental Earth Sciences, 66(3): 903-913.

Devi, R., Tesfahune, E., Legesse, W., Deboch, B., and Beyene, A. (2008). Assessment of siltation and Nutrient Enrichment of Gilgel Gibe Dam, Southwest Ethiopia. Bioresource Technology, 9(5): 975-979.

FAO (1998a). Ethiopia: Soil Fertility Initiative. FAO, Investment Centre Division. Concept Paper, Rome.

FAO/IGADD/Italian Cooperation (1998b). Soil and Terrain Database for Northeastern Africa and Crop Production Zones. Land and Water Digital Media Series \# 2. FAO, Rome.

FAO/IIASA/ISRIC/ISS-CAS/JRC (2009) Harmonized World Soil Database (version 1.1). FAO, Rome, Italy and IIASA, Laxenburg, Austria. 
GLCF (2009). The Global Land Cover Facility

(GLCF)

University of Maryland. URL: http://glcf.umiacs.umd.edu/.

Gobin, A., Govers, G., Jones, R., Kirkby, M., Kosmas, C. (2002). Assessment and Reporting on Soil Erosion Background and Workshop Report. Technical Report. European Environment Agency.

Hawando, T. (1995). The Survey of the Soil and Water Resources of Ethiopia. UNU/Toko.

Hurni, H. (1985). Soil Conservation Manual for Ethiopia: A Field Guide for Conservation Implementation. Ethiopia. Community Forests and Soil Conservation Development Department Ministry of Agriculture: Addis Ababa.

Jarvis, A., Reuter H.I., Nelson A., and Guevara E. (2008). Hole-filled SRTM for the globe Version 4, available from the CGIAR-CSI SRTM $\quad 90 \mathrm{~m} \quad$ Database (http://srtm.csi.cgiar.org).

JZMSR (Jimma Zone Meteorology Station Report) (2004). Ten year's calamite data. JZMS. Jimma, Ethiopia.36p.

Kebede, T. and Mikru, Z. (2006) Effect of Different Cover Crops on Runoff and Soil Loss. Proceeding: Workshop organized by UNESCO chair in water resources entitled "International Sediment Initiatives Conference (ISIC)", Nov. 12-15, 2006, Khartoum.

Kebede, T. and Yaekob, T. (2009). Research and Development of Vetiver Grass (Vetiver zizanioides L.) in Ethiopia. Jimma Research Center, Ethiopia.

Kechero, Y. (2008). Gender responsibility in smallholder mixed crop-livestock production systems of Jimma zone, South West Ethiopia. Livestock
Research for Rural Development 20

(1) Retrieved January 11, 2010. http://www.lrrd.org/lrrd20/1/yise200 11.htm.

Kissi, E., Poesen, J., Diels, J., Broothaerts, N., and Vanopstal, M. (2011). Spatial and Temporal Variability of Sediment Yield of Gilgel Gibe Catchment, Southwestern Ethiopia. In: Water 2011 - Integrated water resources management in tropical and subtropical drylands. 19-26 September 2011, Mekelle, Ethiopia.

Kumar, S. and Kushwaha, S.P.S. (2013). Modeling Soil Erosion Risk Based on RUSLE-3D Using GIS in a Shivalik Sub-Watershed. J. Earth System Science, 122(2): 389-398.

Moore, I.D.and Wilson, J.P. (1992). Length-Slope Factors for the Revised Universal Soil Loss Equation: Simplified Method of Estimation. $J$. Soil and Water Conservation, 47(5): 423-428.

Neitsch, S.L., Arnold, J.G., Kiniry, J.R., Williams, J.R. and Kiniry, K.W. (2002). Soil and Water Assessment Tool Theoretical Documentation. TWRI report TR-191, Texas Water Resources Institute, College Station.

Niu D.; Wang H and Lai L. (2003) Soil Erosion and Conservation; http://159.226.205.16/curriculum/3w/ 01/cause/index.html; visited on November 12, 2009.

Omar, A.A., Edinam, K.G., Olav,i L. (2013). Causes and Impacts of Land Degradation and Desertification: Case Study of the Sudan. Int. J. Agriculture and Forestry, 3(2): 4051. doi: 10.5923/j.ijaf.20130302.03.

Ozsoy, G, Aksoy, E., Dirim, M.S. and Tumsavas, Z. (2012). Determination of Soil Erosion Risk in the Mustafakemalpasa River Basin, Turkey, Using the Revised Universal 
Soil Loss Equation, Geographic Information System, and Remote Sensing. Environ. Manage., 50(4): 679-694.

Saavedra, C. (2005). Estimating spatial patterns of soil erosion and deposition in the Andean region using geo-information techniques, A case study in Cochabamba, Bolivia. $\mathrm{PhD}$ Thesis, Wageningen University, The Netherlands.

Shiferaw, B. and Holden S.T. (1999). Soil Erosion and Smallholders' Conservation Decisions in the Highlands of Ethiopia. World Developemnt, 27(4): 739-752.

Shiferaw, A. (2011). Estimating Soil Loss Rates for Soil Conservation Planning in the Borena Woreda of South Wollo Highlands, Ethiopia. $J$. Sustainable Development in Africa, 13(3): 87-106.

Sonneveld, B. (2002). Land under Pressure: Impact of Water Erosion on Food Production in Ethiopia, Shaker publishing the Netherlands.

Stone, P. and Hilborn, D. (2000). Universal Soil Loss Equation (USLE). Ontario Ministry of Agriculture; Food \& Rural Affairs. Agdex\#: 572/751. http://www.omafra.gov.on.ca/english /engineer/facts/12-051.htm, Retrieved on August 12, 2012.

Tamene, L. and Vlek, P.L.G. (2008). Soil Erosion Studies in Northern Ethiopia. In: Land Use and Soil Resources (ed. by A.K. Braimoh and P.L.G Vlek) 73-100, Springer, The Netherlands.

Tesfahunegn G.B. (2011). Soil erosion modeling and soil quality evaluation for catchment management strategies in northern Ethiopia. PhD Thesis, University of Bonn, Germany.

Tolossa, T. and Tigre, W. (2007) The Prevalence and Economic Significance of Bovine Fasciolosis at Jimma Abattoir, Ethiopia. $J$. Veterinary Medicine, 3(2).

USAF (2009). Landscape Design Guide Erosion Control. http://www.afcee.brooks.af.mil//dg/s 18ErosionControl/c02Causes.html; viewed on December 5, 2009.

Van der Knijff, J.M., Jones, R.J.A. and Montanarella, L. (1999). Soil Erosion Risk Assessment in Italy. European Commission Directorate General, Joint Research Center. Space Applications Institute. http://eusoils.jrc.ec.europa.eu/esdb_a rchive/eusoils_docs/other/er_it_new. pdf. Viewed on May 23, 2012 